Available online at: http://proceeding.rsfpress.com/index.php/pss/index

LPPM UPN “Veteran” Yogyakarta Conference Series

Proceeding on Political and Social Science (PSS)

Volume 1 Number 1 (2020): 309-322

\title{
The Potencies of Cave Geo-Ecotourism Development in Tanjungsari District, Gunungkidul Regency, Yogyakarta Special Region
}

\author{
Sari Bahagiarti Kusumayudha, Muhammad Faizal Zakaria, Bambang Prastistho, \\ Istiana Rahatmawati, Tuti Setyaningrum \\ Universitas Pembangunan Nasional Veteran Yogyakarta \\ Email address faizal.zakaria19@gmail.com
}

\begin{abstract}
Tanjungsari is one of the districts in the Gunungsewu Geopark area, Gunungkidul Regency. Since Gunungsewu was declared as a Global Geopark Network area by Unesco, the tourism sector in this area has grown rapidly. Tanjungsari District does not want to be left behind in developing the tourism sector. Therefore it is necessary to trigger the development of tourism. In this district, there are several caves that have the potential to be developed, including Cave Bentar, Cave Cabe, Cave Tritis, Cave Grengseng, and Cave Pakubon, which have their own uniqueness and appeal in terms of morphology, endokarst, and legends. The development of these potential places is expected to be able to improve the economic sector and the welfare of the surrounding community. In order for the caves in Tanjungsari District to be able to compete, the concept of development must be different and not yet developed in other places, namely cave geo-ecotourism. In connection with the above-mentioned matters, research, studies, and feasibility studies are conducted on the potential development of cave geo-ecotourism. The activities carried out include mapping the distribution of geomorphology, geological structures, subsurface conditions, underground water availability using the ERT geoelectric method, and cave tracking. The results of this study are a cave map and an inventory of the potential of the cave.
\end{abstract}

Key Words: cave, karst, geo eco-tourism, Geoelectric Method

\section{INTRODUCTION}

This is an open access article under the CC-BY-NC license.

Tanjungsari District is located in a karst landscape area that has been designated as a Global Geopark Network (GGN) area by UNESCO, namely Gunungsewu. Realizing this, Tanjungsari District needs to improve its status, by developing its natural potential. In this area, there are several karst caves that are expected to be developed as tourist destinations, namely Bentar Cave, Cabe Cave, Grengseng Cave, Pakubon Cave, and Tritis Cave. These caves have ornaments, including stalactites and stalagmites which are unique in shape, as well as interesting legends. 
So that the development of cave tourism can be used as a mainstay and superior area for the region, it is necessary to explore its uniqueness which is different from other places and to build safety and comfort for visitors. Therefore it is necessary to carry out studies and research regarding the factors of uniqueness, safety, and comfort so that they are able to compete with other cave tourism objects that have developed. Based on the description above, it is necessary to conduct research on the potential, feasibility study to develop cave tourism in Tanjungsari District with the concept of geo-ecotourism.

According to data from the Central Statistics Agency of Gunungkidul Regency (2018), Tanjungsari District has an area of 71.63 square kilometers and or 4.82 percent of the area of Gunungkidul Regency. The topographic condition of Tanjungsari District is an area of karst hills with a thin layer of soil, has a slope above $40 \%$, and at an altitude between 100 300 meters above sea level.

This study was conducted covering the area of Tanjungsari district (Figure 1), with the aim of conducting a study and analysis of the potential of caves in the Tanjungsari district so that they can be developed as a geo-ecotourism site for caves. Mapping subsurface conditions using the Dipole-Dipole Geoelectric geophysical method, followed by cave tracing.

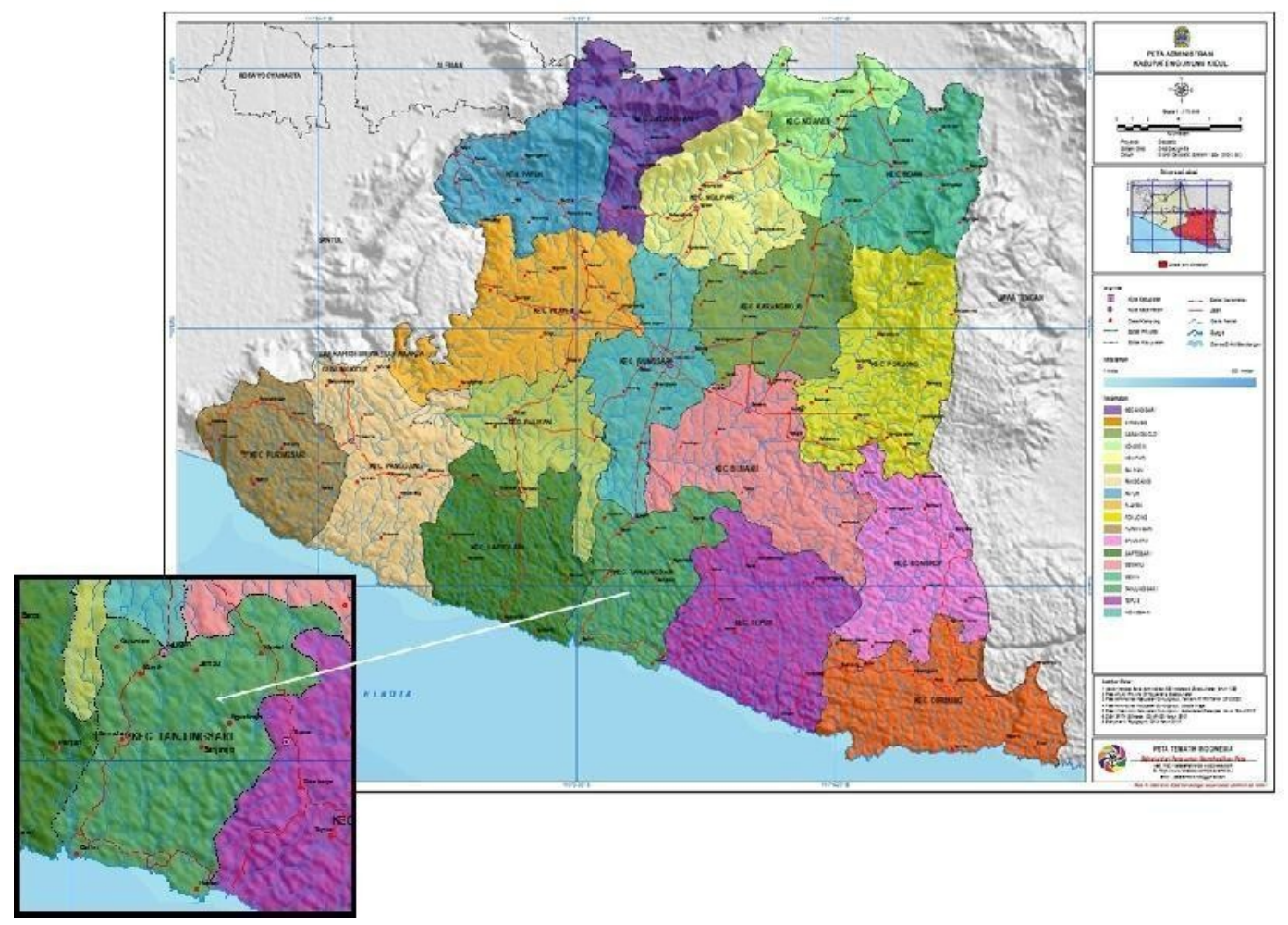

Figure. 1. Location map of Tanjungsari District, Gunungkidul Regency 


\section{RESEARCH METHODOLOGY}

The research will be carried out by applying analytical, descriptive, and survey methods, including geological, geomorphological, and geophysical, as well as economic mapping. The approach applied in this research is mapping of geomorphological distribution and geological structures at selected sites, identification of the distribution of cave passages, and the existence of underground flows to support geo-ecotourism development, with geoelectric methods. The data used consists of secondary data and primary data. Secondary data includes a variety of information from the results of existing research and studies. Primary data is obtained through surveys, investigations, and field mapping. Geological studies that will be carried out include analyzes of geomorphology, petrology, stratigraphy, and geological structures, as well as geophysical applications of the Geoelectric (ERT) method, followed by cave tracking. As it may be informed, that cave geo-ecotourism is a concept of cave tourism development based on their excellence and uniqueness of the geological conditions, with an ecosystem and environmental perspective.

\section{FINDING AND DISCUSSION}

\section{III.1. Geology}

The Gunungsewu area, where Tanjungsari District is located, is physiographically located in the Southern Mountain Zone of Central Java - East Java (Van Bemmelen, 1949). Van Bemmelen divided the mountains into 3 sub-zones, namely the Baturagung - Panggung Plopoh sub-zone in the north, the Wonosari plateau in the middle, and the Gunungsewu subzone in the south. The Baturagung sub-zone is built by volcanic rock groups called the Besole Group (Suyoto, 1994 in Kusumayudha 2002). The Besole Group consists of the Kebo - Butak Formation, the Semilir Formation, and the Nglanggran Formation. The Wonosari plateau sub-zone is occupied by carbonate rocks of the Kepek Formation. The Gunungsewu sub-zone is karst hills with a relatively west-east axis, with a height difference of $10 \mathrm{~m}-100$ $\mathrm{m}$, and hills with a diameter of $50 \mathrm{~m}-300 \mathrm{~m}$. The total area of the Gunungsewu sub-zone is approximately $1500 \mathrm{~km} 2$, consisting of approximately 45,000 large and small hills (Kusumayudha, 2002).

Geologically, the Wonosari plateau is a syncline, with an axis orientation of $\mathrm{N}^{\circ} 5^{\circ} \mathrm{E}$ $\mathrm{N} 255^{\circ} \mathrm{E}$, and a slope of less than $10^{\circ}$, while the Gunungsewu hills are homoclinic in general tilting to the south, with a slope of the bed between $5^{\circ}$ and $15^{\circ}$. The pattern of faults, fractures, and fractures in the Gunungsewu area shows a general direction of northwest-southeast and northeast-southwest (Figure 2.) (Kusumayudha, 2002). 


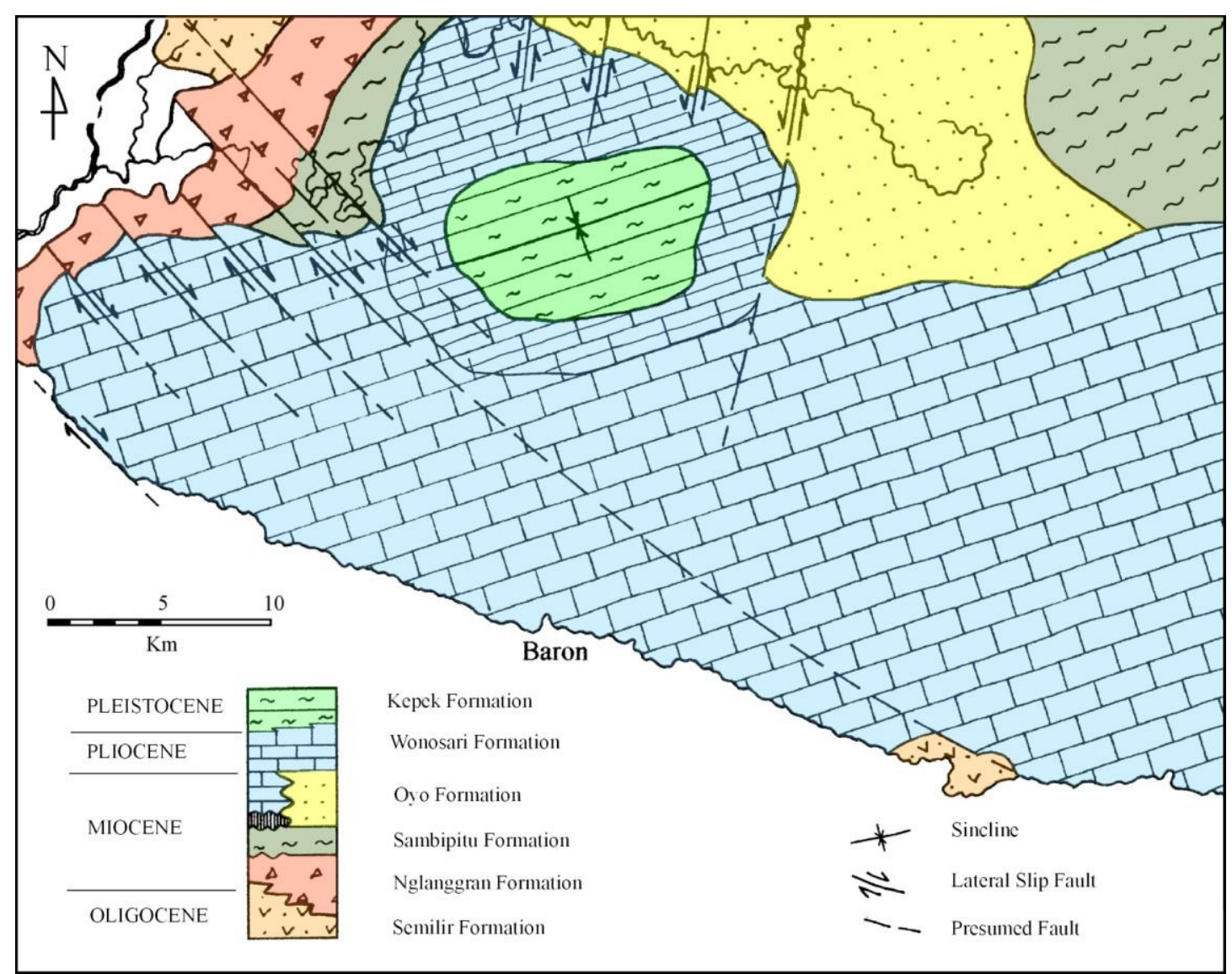

Figure. 2. Geological Map of the Gunungsewu Area (Kusumayudha, 2002)

Geomorphologically, the study area displays a hilly karst topography, with a height difference of $10 \mathrm{~m}-30 \mathrm{~m}$, and the hilly diameter ranges from $50 \mathrm{~m}-200 \mathrm{~m}$. Macro karst is found in the form of conical hills, dolines, uvulas, and loves, while micro karst and lapies which are classified as exokarst are also found in the study area.

In terms of lithology, the study area consists of limestones of the Wonosari Formation. Based on the petrological assessment, referring to Moore (1989), the lithofacies in the study area consists of reef limestones, and bedded limestone, (Figure 3) Limestone has undergone karstification, including in the adult stage (Esteban, 1996), marked by the intensive process carbonate dissolution, resulting in caves with ornamental variations such as stalactites, stalagmites, and flowstones. Limestone is geologically from the Middle Miocene to the late Miocene. Figure 5. shows the distribution of lithofacies in the study area. The geological structure in general shows a homoclinic with an inclination of less than $10^{\circ}$, to the south. 


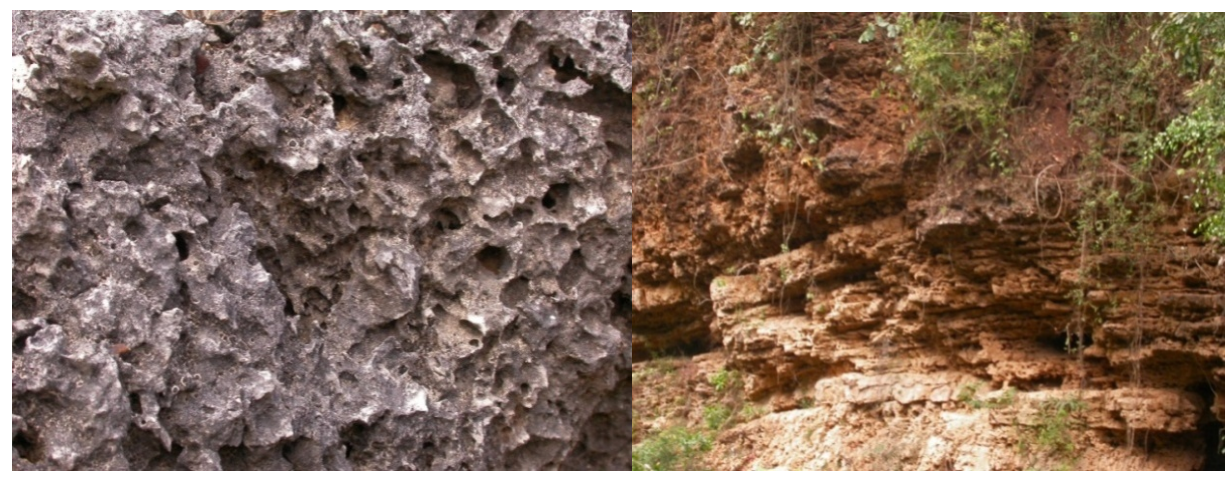

Figure. 3. Reef limestone (left) and bedded limestone (right)

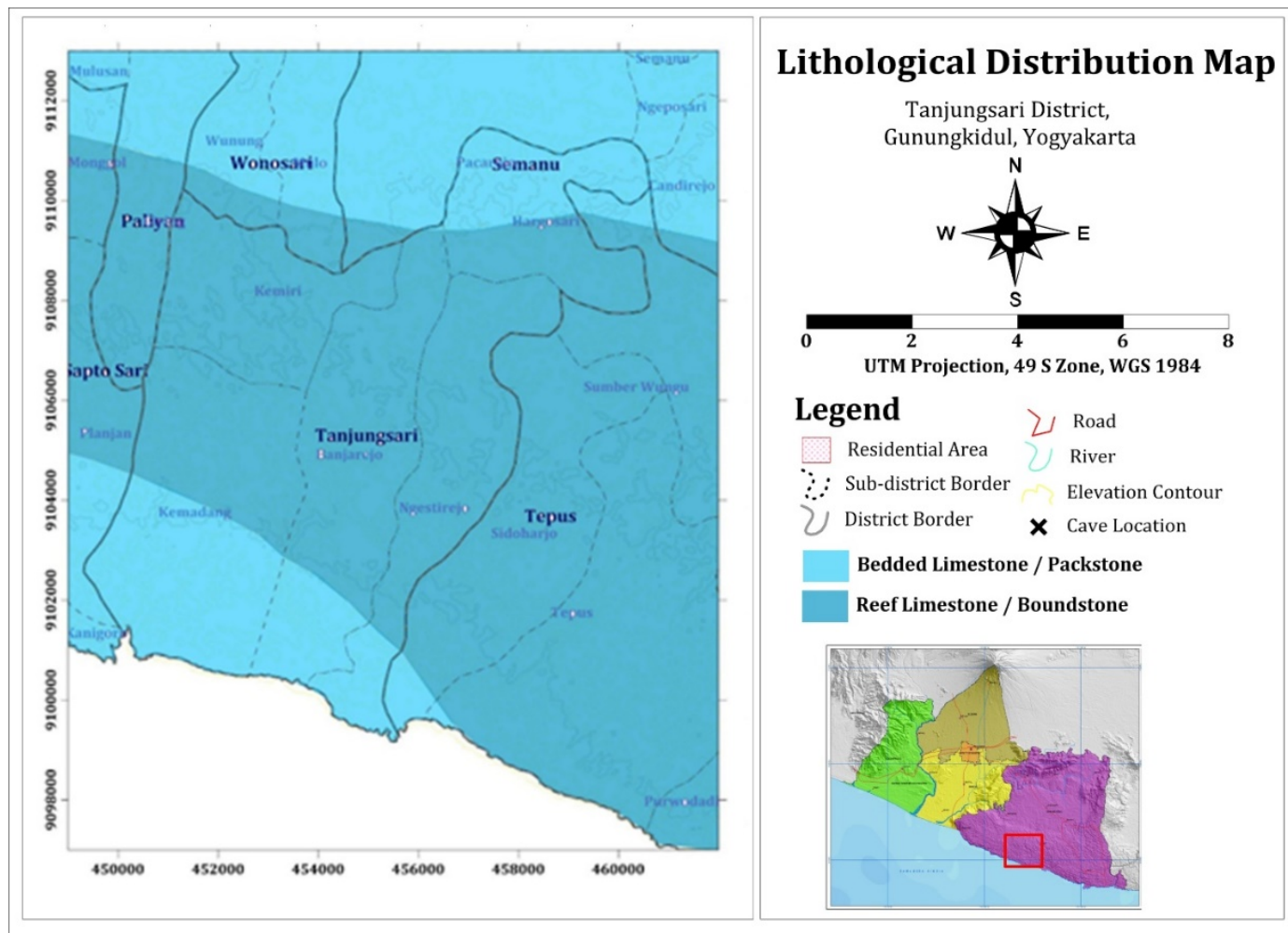

Figure. 4. Lithological distribution of the Tanjungsari and surrounding area

\section{III.2. Hydrogeology, Conduits, and Subsurface Flow.}

In the Gunungsewu karst hydrogeological system, there are four watersheds (river basins) that act as the drainage for Gunungsewu, namely the Bribin River Watershed, Kali Suci Watershed, Kali Serpeng Watershed, and Kali Tegoan Watershed. Subsurface flows in the watershed generally discharging in the Baron Vaucluse (Kusumayudha, 2002, 2005). The direction of flow of the underground channel in addition to the pattern of the crack structure, also in accordance with the dip direction of the limestone bedding planes. 
There are many karst caves in the study area, including Cave Bentar, Cave Cabe, Cave Tritis, Cave Grengseng, and Cave Pakubon. The caves have a horizontal or vertical orientation. Caves in karst areas are generally associated with underground flows. The underground river flow pattern in the study area has a relatively general direction of northeast-southwest and north-south. The main underground river flow in the study area is the Bribin River (Kali Bribin) which empties into the Indian Ocean in Baron Bay (Kusumayudha, 2002). The underground rivers in the Study Area are interpreted to form a sub-rectangular-dendritic pattern, which is a combination of a dendritic pattern with branching junctions that relatively form an almost vertical angle (Kusumayudha \& Santoso, 1998). With this subsurface investigation, it is hoped that the existence of the underground flow system in the study area can be traced.

The configuration of the bedrock in the Gunungsewu area which forms such highs, lows, ridges, basins, and subsurface valleys, caused different patterns and direction of underground flow, thus forming a hydrodynamic zone separation in this area. Based on the separation of hydrodynamic zones, discharge patterns, and the distribution of existing springs, the hydrogeological system in the Gunungsewu area can be divided into 3 sub-systems, namely the Panggang Sub-system in the west, the Wonosari-Baron Sub-system in the middle, and the Sanding Sub-system. in the east (Kusumayudha 2002). The study area is included in the Wonosari - Baron Sub-system.

In the Wonosari-Baron sub-system, there is a very striking difference in groundwater level, between the area in the north which is occupied by bioclastic limestones (wackestone), and the area in the south which is composed of reef limestones (boundstone and packstone). In the northern part, groundwater is found at a depth of $5-10 \mathrm{~m}$, while in the southern part the depth of groundwater reaches $150 \mathrm{~m}$ or more. Apart from being composed of different carbonate facies, these two parts are also separated by faults. These faults are interpreted to act as an insulator for the groundwater movement.

\section{III.3. Cave geo-ecotourism potencies of tanjungsari area}

Caves are part of the endokarst which generally developed into special interest tourism objects, namely cave tracking. There are several karst caves that have unique ornaments, flora, and fauna in Tanjungsari District, which are intended for tourism development by the local people, they are Cave Bentar, Cave Cabe, Cave Tritis, Cave Grengseng, and Cave Pakubon. The description of each cave is as the following.

\section{III.3.1.Cave Bentar}

Cave Bentar is a new destination that has an extraordinarily beautiful charm with its location at Jrakah Hamlet, Hargosari Village, Tanjungsari District, Gunungkidul Regency. This cave is managed by the village community, and the community mutually cooperates with the local government trying to develop the cave tourism.

Cave Bentar morphology can be classified as a vertical cave (Figure 5). Its formation is controlled by the natural limestone fractures that make up the cave, which then interacts with meteoric water to form a vertical shaft. Inside the cave, there is a natural window on the roof of the cave, causing light from outside to be able to penetrate into the cave. This place is 
very interesting as a means of photography to display breakthrough images of light (Figure 6)

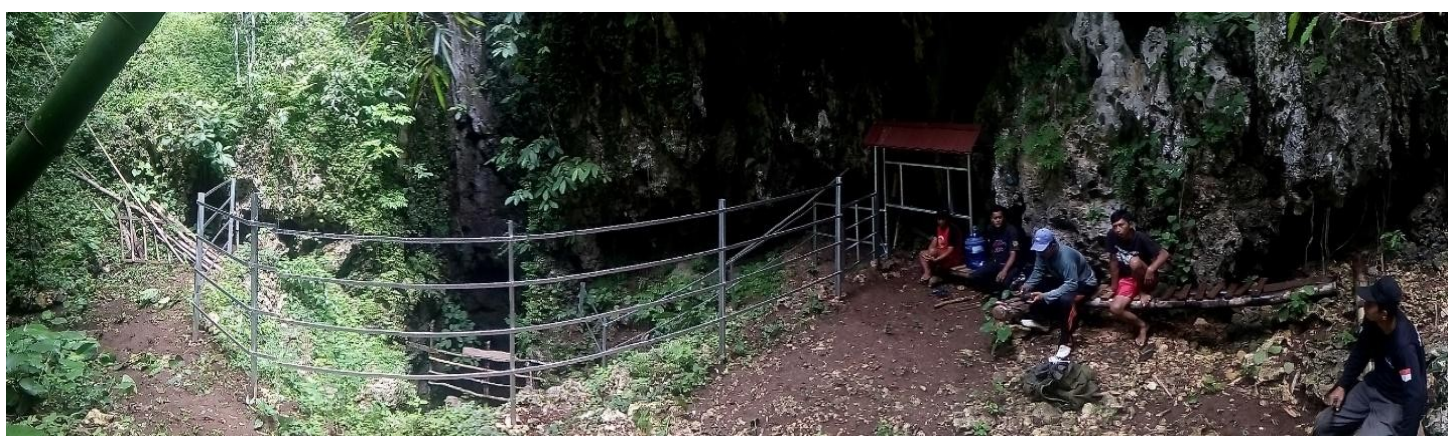

Figure. 5. In front of Cave Bentar

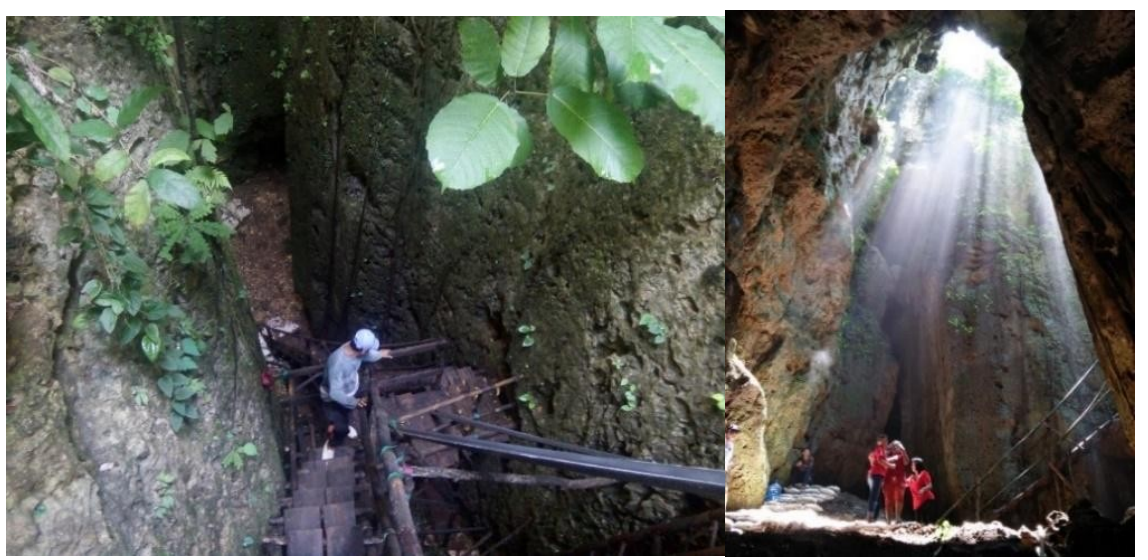

Figure. 6. Inside of Cave Bentar

\section{III.3.2. Cave Cabe}

Cave Cabe is located in Ngestirejo, Tanjungsari, Gunung Kidul. Cave Cabe is assumed to be a Cultural Heritage Site because based on a short story told by Dukuh Timunsari, Slamet Setiawan, in 1996 a historical object was found in Cave Cabe. This object was declared by the Yogyakarta Special Territory Cultural Heritage Conservation Center (BPCB) as Nganjatan I and II inscriptions, which are a bronze inscription with a length of $48 \mathrm{~cm}$, a width of $18 \mathrm{~cm}$, and a thickness of $0.2 \mathrm{~cm}$ with the inscription of ancient Javanese script consisting of 12 lines of writing. . These objects are currently stored at BPCB

Inside Cave Cabe, there are ornaments in the form of stalactites having a unique shape, like a crystal chandelier, which is different from the shape of stalactites in general (Figure 7). On the other hand, there were no stalagmites at that place. This indicates that the bottom of the cave is frequently or periodically passed by water flow so that the calcite crystal deposits that form at the bottom of the cave are dissolved and eroded by the flow of water so that stalactites cannot be formed. The cave room does not have stalagmite in the Chili Cave which is quite wide, with a diameter of $10-12 \mathrm{~m}$. If later this cave is developed as a tourist 
destination, then this room can be used as a meeting place or used as a sensational cafeteria in the cave. The development of a meeting room or cafeteria can be equipped with an attractive lighting system without reducing the natural atmosphere of the cave.

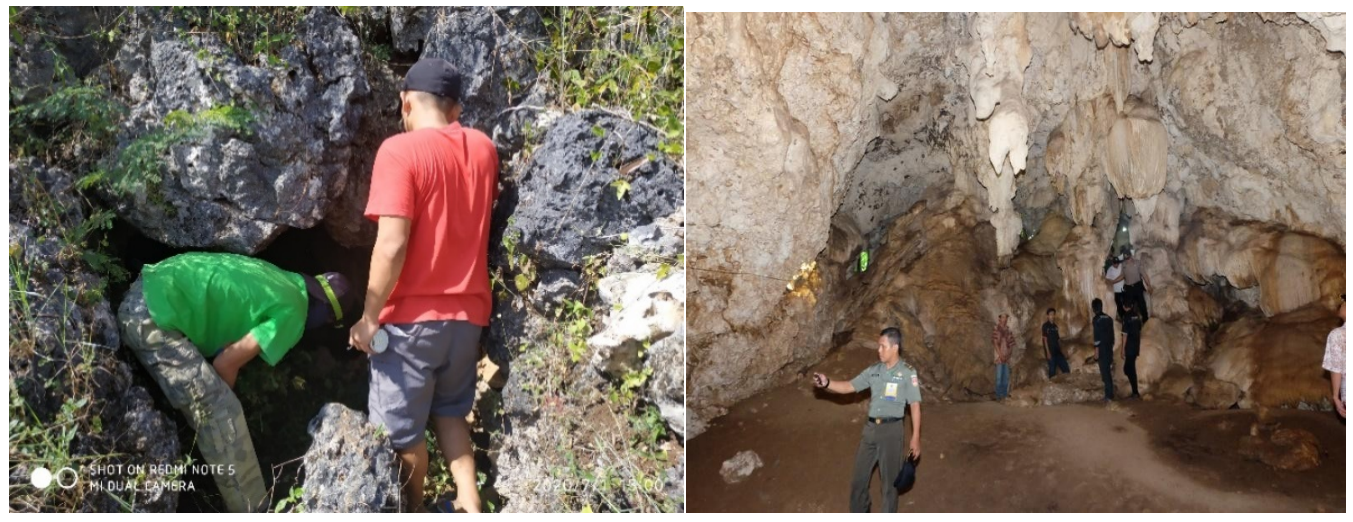

Figure 7. The environmental situation of cave Cabe (left), the mouth of Cave Cabe (right)

\section{III.3.3. Cave Tritis}

Cave Tritis is located in Jaten Hamlet, Ngestirejo Village, Tanjungsari District, Gunungkidul Regency. Inside the cave, there are stalagmite and stalactite rocks. This cave is also often a place for ritual meditation or meditation. To the west of the cave, there is a lake which can be an alternative tour. Based on information from residents, the sediment at the bottom of the lake has been dredged in the hope that the lake's capacity will be greater, and the lake's water will increase. However, the result of the dredging of the sediment at the bottom actually resulted in the lake leaking, because the dredging reached the hollow part of the bedrock. Another uniqueness of Cave Tritis is the discovery of a layer of volcanic ash deposits near the mouth of the cave (Figure 8). 


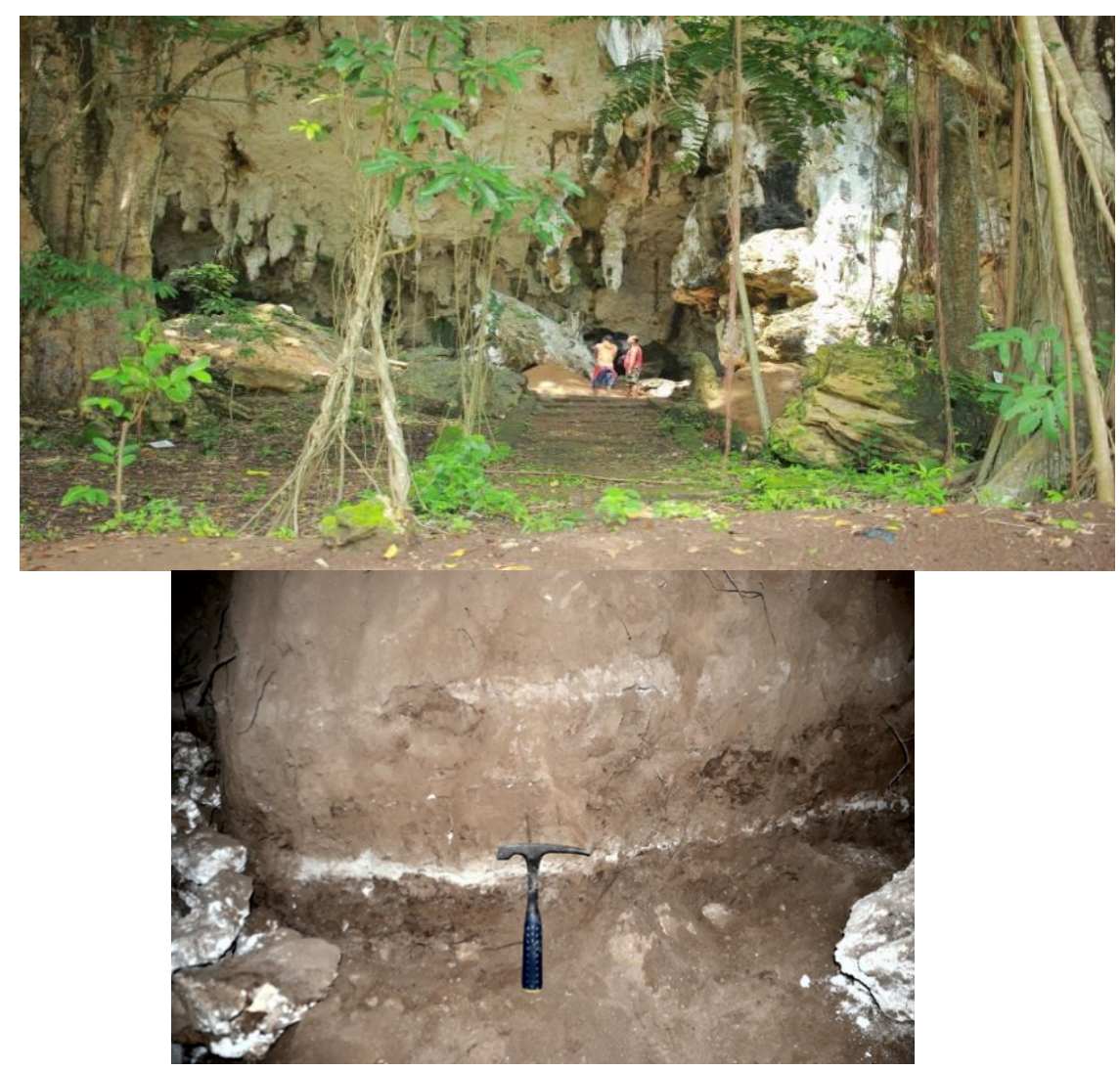

Figure 8. Cave Tritis (above) and volcanic ash deposit (below)

\section{III.3.3. Cave Grengseng}

Cave Grengseng which is located in Kelor Lor, Kemadang Village, Tanjungsari District, Gunungkidul Regency. To be precise, it is located north of Kanigoro State Elementary School. Grengseng Cave is located in two mountains of land belonging to the village treasury. The inside of the cave is wide and wide, there are cave ornaments in the form of stalactites and stalagmites. Between the stalactites and the stalagmites that have met together to form karst pillars. According to residents around this cave, it can penetrate into residential areas.

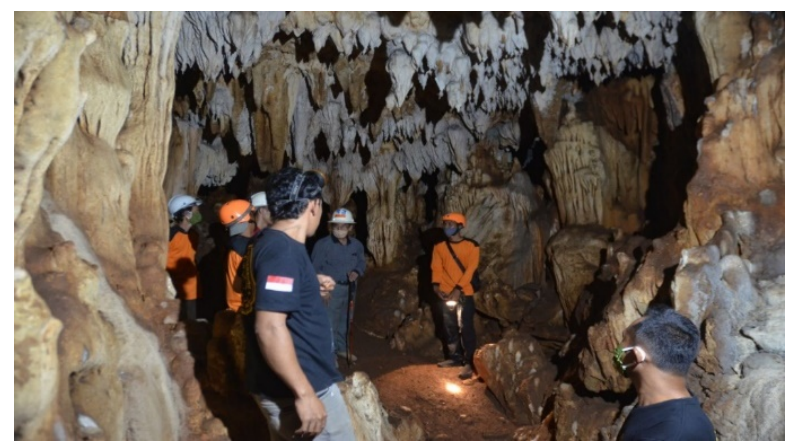


Figure. 9. On side of the cave Grengseng and its ornaments

\section{III.3.4. Cave Pakubon}

Cave Pakubon is located at Padukuhan Ngasem Rt 001 Rw 009, Kemiri Village, Tanjungsari District, Gunungkidul Regency. Access to the cave is very easy, namely towards Baron beach, entering Padukuhan Glagah Jl. Baron $\mathrm{km} \mathrm{12,300} \mathrm{m}$ after the Tanjungsari police station take a right through the asphalt district road $-/+1 \mathrm{~km}$. With an adequate road and wide enough access to Gunungkubon cave is very easy.

Because it will only be opened as a new tourist destination, the facilities around the cave are still minimal, including the parking lot is still one with the homestead yard, the entrance and exit of the cave are still simple with emergency stairs made. Small rooms and others are not yet available. In front of the cave, there is also an area/vehicle large enough for camping or for out bond activities for tourists.

Inside the cave there is a large enough room, on the roof of the cave, there are stalactites, some of which are unique in shape, which is like a crystal chandelier. There are no stalagmites in the aas part of the cave. This indicates that Cave Pakubon is often traversed by water flows.

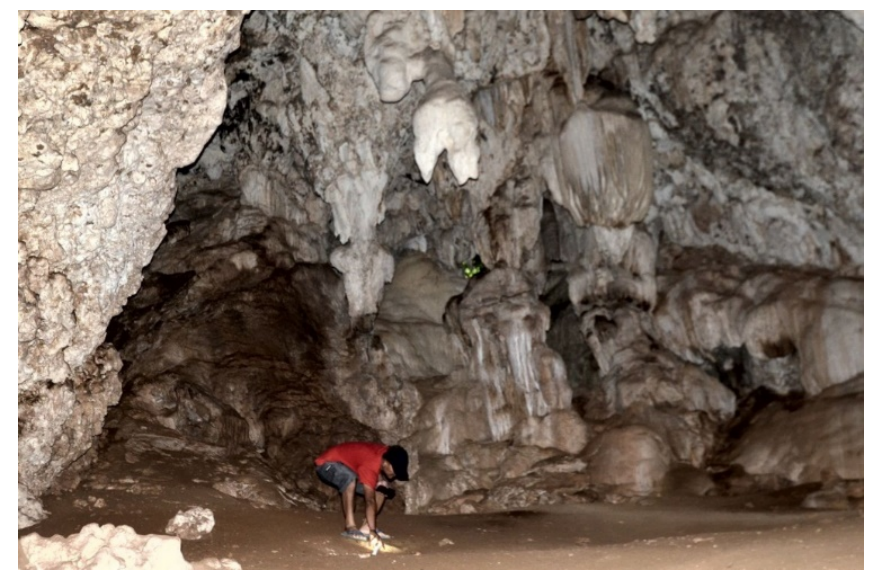

Figure. 10. Inside of Cave Pakubon, there is a unique form of stalagtite: crystal chandelier like

\section{III.4. Subsurface Identification to support Geo-ecotourism}

By applying the ERT method, in the area of near Cave Tritis, the results of the geoelectric path are shown in this chapter. The geoelectric cross-section of the inversion result can be seen in the form of a subsurface resistivity distribution section (Figure 9 and Figure 10). The cross-section of the resistivity value is then interpreted to be the geological meaning associated with the rock type. The rocks in the study area are dominated by limestone. Physically, limestones tend to have high resistivity values. The ERT line runs east-west and is $400 \mathrm{~m}$ long. 


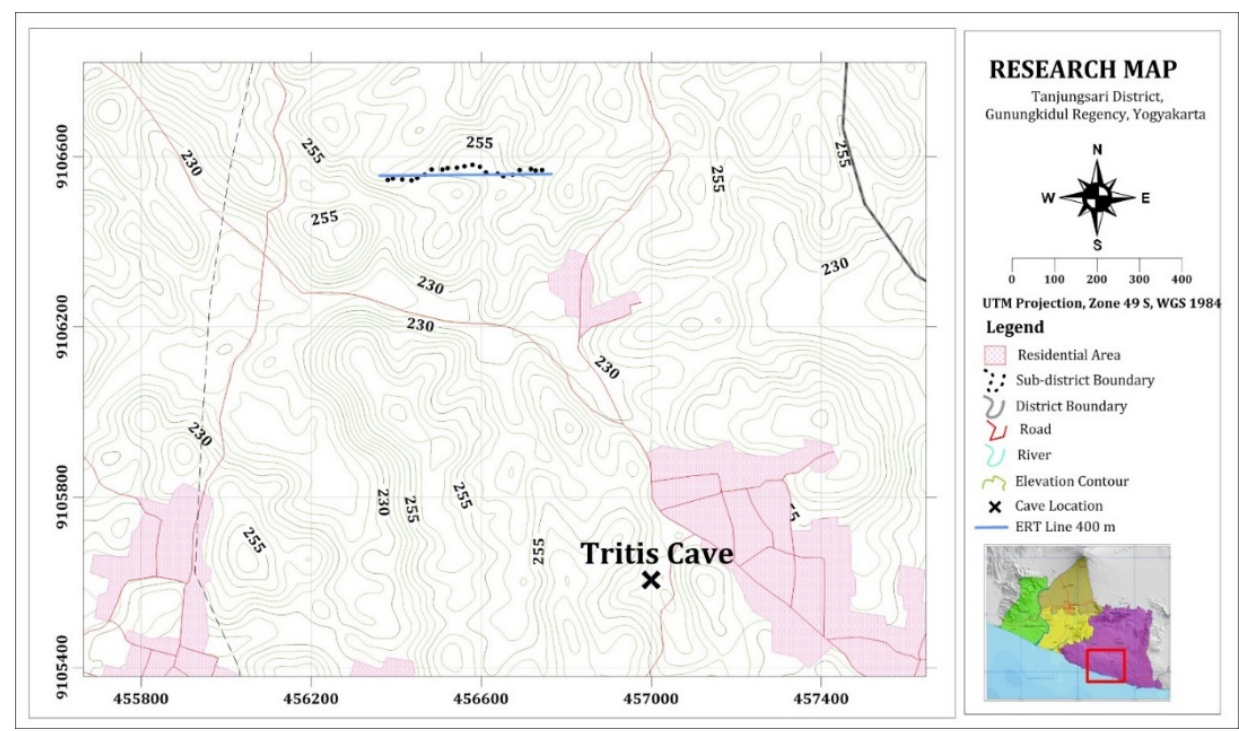

Figure. 09. The location of the traverse of ERTmethod application

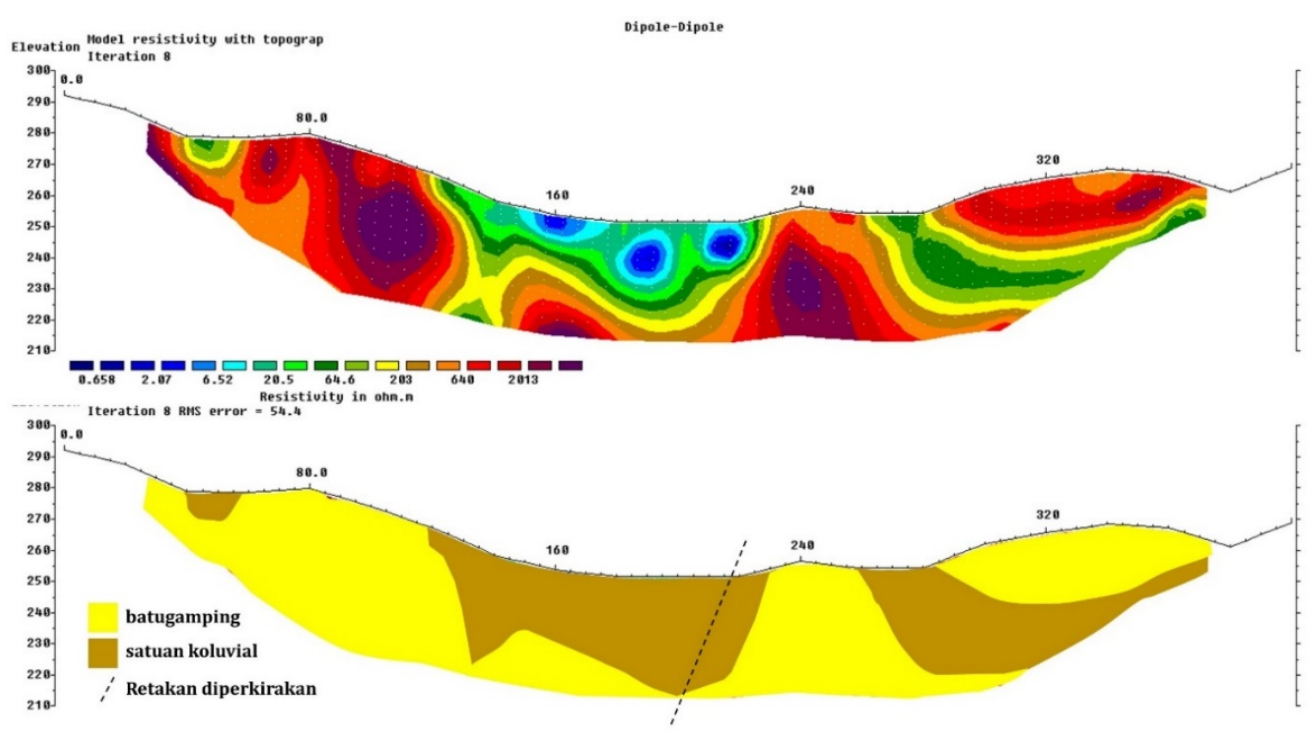

Fig. 10. Result of ERT (above) and the interpretation (below)

The resistivity value on the ERT line is dominated by high resistivity ( $>400 \mathrm{ohms}$ ) which is indicated in orange to dark red/purple. This high resistivity value extends from the beginning of the 0 -meter line to the end of the 400-meter line. This high resistivity value is defined as limestone. Limestone on the ERT trajectory is characterized by white color, massive structure, amorphous texture, and mineral composition of monomineralic carbonate (CaCO3). The limestones in the study area are reef limestones. 
Low resistivity values on the ERT line are shown in blue to yellow. This low resistivity is shown at the 100th meter to the 220th meter, with a maximum depth of $40 \mathrm{~m}$. This low resistivity value is defined as colluvium. Colluvium in the study area is characterized by a reddish-brown color and is composed of weathered sediment from the surrounding limestone cliffs.

The analysis is carried out in an integrated manner from the results of geological mapping, ERT measurements, and information from the community. The cracks informed by the community are located at 200 meters on the ERT trajectory and are in the colluvium rock unit. Colluvium rocks have high porosity so that they can pass through water. From the results of the ERT line, the colonial rock units are in the form of a basin with a base of limestone. Limestone itself is a waterproof layer so it is water-resistant. The rock configuration as mentioned above, allows water to be trapped in that place (basin). In fact, water does not collect in that place. This means that at the bottom of the basin there are cracks that allow limestone to pass through the water. The cracks are connected to the cave by dynamic water flow. The depth of the cave cannot be determined from the ERT results because it has a low penetration depth.

This study has also done a vace tracing to map the subsurface situation. Locations, where the cave tracing is done, were Cave Bentar and Cave Grengseng, with the result is showed in Figure 11 and figure 12.

Peta Gua Bentar

Kecamatan Tanjungsari, Gunung Kidul
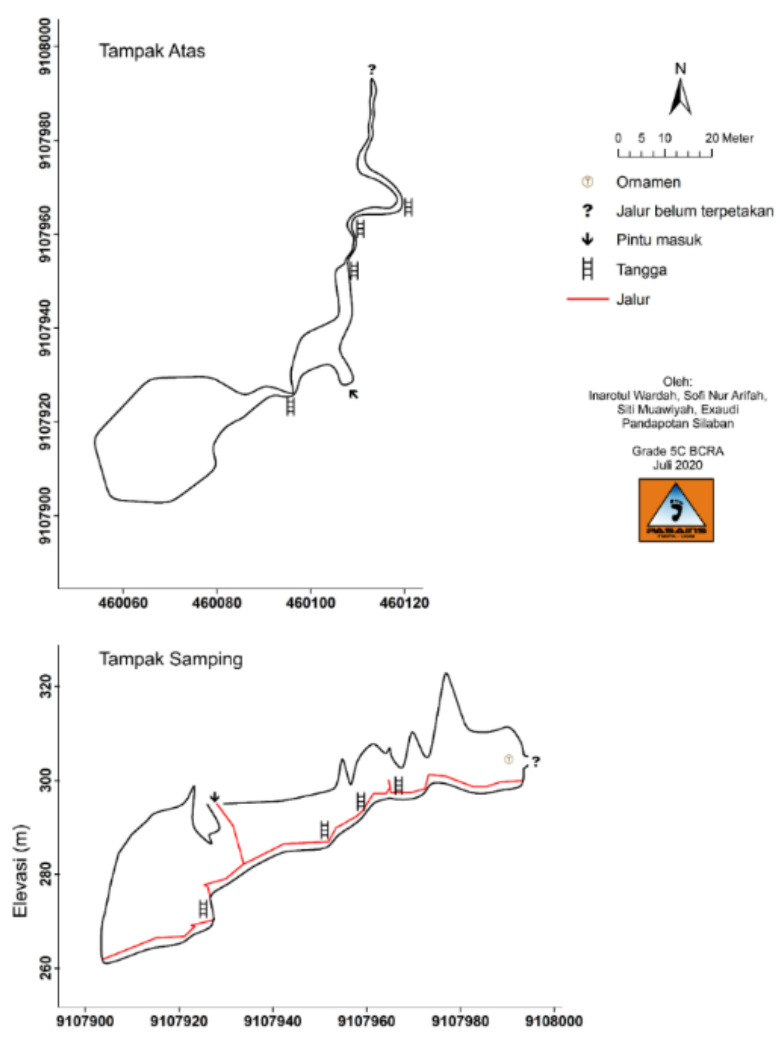


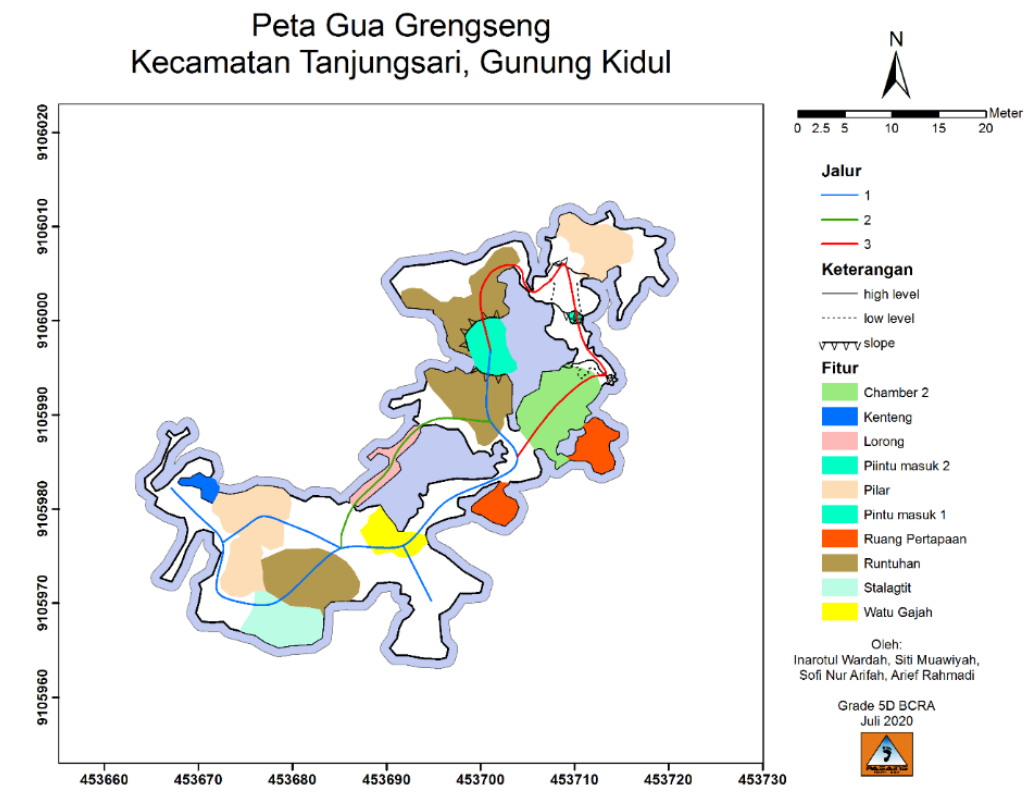

Figure. 12. Situation map of Cave Grengseng

\section{CONCLUSION AND FURTHER RESEARCH}

1.Tanjungsari area is geomorphologically forms a karst topography, apart of the Gunungsewu Geopark. Lithology composing the study area is included in Reef Limestone and based on the pathological assessment it is classified into boundstone and bedded limestone included in packstone.

2.There are 5 (five) caves with their uniqueness in terms of ornaments and history, identified able to be developed to become geo eco-tourism, namely Cave Bentar, Cave Cabe, Cave Tritis, Cave Grengseng, and Cave Pakubon.

3.Based on ERT geophysical method application, it can be identified that in the surrounding area of Cave Tritis, there is a basin geometry of the colluvium from 100th $\mathrm{m}$ to 220th $\mathrm{m}$ with a maximum depth of $40 \mathrm{~m}$. There is a crack on the base of the basin that is connected to the cave with dynamic water flow on the subsurface. The depth of the cave is unknown because of the low penetration depth of the method.

4.By conducting cave tracking, the situation and configuration of some samples of caves, i.e. Cave Bentar and Cave Grengseng can be well described. It is in order to provide information for the development of the caves for a tourist destination. 


\section{ACKNOWLEDGMENT}

This study was held by funding support of the Institute of Research and Community Service of Universitas Pembangunan Nasional Veteran Yogyakarta. In relation to that, the authors express a high appreciation and deep gratitude to the institution for support in the operation of this study

\section{REFERENCES}

Amrin, I., Purwanto, M.S., Utama, W., dan Syaeful A. (2018), Identifikasi Sistem Sungai Bawah Tanah Daerah Karst Menggunakan Metode Very Low Frequency, PacitanBJURNAL TEKNIK ITS Vol. 7, No. 1 (2018), 2337-3520

Cahyadi A. (2013), Tingkat Pengetahuan Masyarakat terhadap Keberadaan dan Penyebab Kerusakan Sumberdaya Air Sungai Bawah Tanah di Kawasan Karst Gunungsewu, Geomedia, Vol 11, No. 2: 253 -260

Cahyadi, A. (2017), Sumberdaya Lahan Kawasan Karst Gunungsewu, https://www.researchgate.net/publication/326114734_Sumberdaya_Lahan_Kawasan

Karst_Gunungsewu

Kusumayudha, S.B. (2018), Mengenal Hidrogeologi Karst, penerbit Pohon Cahaya, Yogyakarta

Kusumayudha, S.B \& Ciptahening, A.N. (2016), Correlation between Tectonic Environment and Chracteristics of Mass Movement (Landslides): A Case Study from Java, Indonesia, Journal of Geological Resource and Engineering, Vol 4, Number 2: 51 - 62

Kusumayudha, S.B (2002), Sistem Hidrogeologi Gunungsewu, Buku: Sumberdaya Geologi Daerah Istimewa Yogyakarta dan Jawa Tengah, IAGI, Pengda DIY-Jateng, 128 - 139 Kusumayudha S.B. \& A. Santoso, (1998), Daerah Aliran Sungai Bawah Tanah di Gunungsewu Berdasarkan Peta Anomali Gravitasi dan Pola Struktur Geologi, Pros PIT HAGI XXIII: 66- 72

Suyoto, (1994), Sekuen Stratigrafi Karbonat Gunungsewu, Pros PIT IAGI XXIII, Vol I: 6776 Van Bemmelen, R..W., (1949). The Geology of Indonesia, Vol. IA, Gov. Print. Office, The Hague Martinus Nijhoff. https://www.gunungkidulkab.bps.go.id

https://www.kompas.com/skola/read/2020/03/07/110000769/empon-empon-manfaatjenis-dan-bukti-khasiat?page $=$ all. 